\title{
COVID-19 pandemic: a different behavior in children
}

\author{
COVID-19: un comportamiento diferente de la pandemia en niños
}

\author{
Onofre Muñoz-Hernández ${ }^{1}$ and Fortino Solórzano-Santos ${ }^{2 *}$ \\ ${ }^{1}$ Comisión Nacional de Arbitraje Médico, Secretaría de Salud; ${ }^{2}$ Unidad de Investigación en Enfermedades Infecciosas, Hospital Infantil de México \\ Federico Gómez. Mexico City, Mexico
}

In the past days of December 2019, the emergence of a new disease caused by a novel coronavirus was announced in Wuhan, China. By the following month, in January 2020, the virus was identified as severe acute respiratory syndrome type 2 coronavirus (SARS-Cov-2). The disease caused by this virus was named coronavirus disease 19 (COVID-19); as the virus is highly contagious, it spread from China to the world, becoming a global pandemic declared on March 11, 2020, by the World Health Organization (WHO) ${ }^{1}$. SARS-CoV-2 appears to be transmitted mainly through respiratory droplet secretions when infected individuals cough or sneeze, although it has been suggested that other aerosols may also be part of the transmission mechanisms ${ }^{2}$.

Up to May 31, 2020, 215 countries and territories around the world have been affected by COVID-19, with $6,263,905$ confirmed cases and 373,899 deaths. The countries with the highest number of cases are the United States of America, Brazil, Russia, Spain, the United Kingdom, Italy, France, Germany, Turkey, and India. Mexico ranks $15^{\text {th }}$, with 90,664 confirmed cases, of which 1374 are children ${ }^{3,4}$.

Since the beginning of the COVID-19 pandemic, children have been less affected than adults in both severity and frequency. Globally, children infection accounts for $<2 \%$ of cumulative cases ${ }^{5,6}$, among which approximately $5 \%$ developed severe forms. In Mexico, of the total number of cases, $2 \%$ have been individuals $<15$ years of age, and $13 \%$ have required hospitalization. The symptomatology in children is milder, with less frequency of respiratory difficulty, general malaise, and myalgia; in contrast to adults, only about $50 \%$ of children present with fever and cough 7 . Even though it is the same infectious agent, clinical and epidemiological behavior is different between children and adults.

Unlike other viral respiratory infections, children do not appear to be an important vector for acute SARSCoV-2 transmission. Most pediatric cases occur through intra-family contacts, and the reports of child-to-adult or child-to-child transmission are rare. In some studies, carried out in Switzerland and China, in which the source of infection was investigated in children infected with SARS-CoV-2 confirmed by polymerase chain reaction, a predominance of contact with adults (mainly within the family) was found. From these cases, $<3 \%$ were related to contact with another child, although some children were not yet attending school $^{8}$. In another study conducted in China, in hospitalized children, the transmission of the disease by contact with adults was also high ${ }^{9,10}$.

In New South Wales, Australia, nine students and nine staff members infected with SARS-CoV-2 in 15 schools had close contact with a total of 735 students and 128 employees. Only two secondary infections

\section{Correspondence:}

*Fortino Solórzano-Santos

E-mail: solorzanof056@gmail.com
Date of reception: $19-06-2020$

Date of acceptance: 23-06-2020

DOI: 10.24875/BMHIM.20000168
Available online: 03-08-2020

Bol Med Hosp Infant Mex. 2020;77(5):219-220

www.bmhim.com

1665-1146/C 2020 Hospital Infantil de México Federico Gómez. Published by Permanyer. This is an open access article under the CC BY-NC-ND license (http://creativecommons.org/licenses/by-nc-nd/4.0/). 
were identified, but none in the adult staff ${ }^{11}$. The question remains whether the lower number of cases of child-to-child transmission may be influenced by the social isolation that resulted in the children's contact being predominantly familial. In addition to more evidence, these data suggest that children are not significant carriers of COVID-19, even though viral loads are similar to other age groups. Furthermore, the decreased strength of cough might lower the amount of expelled viral particles. It is not well understood why the transmission of SARS-CoV-2 from children to other children or adults is so rarely documented. If school-aged children are indeed low transmitters of the virus, then maybe the opening of schools should not be impeded, as this would help to lessen the social and psychological impact in children ${ }^{12}$.

SARS-CoV-2 uses the angiotensin-converting enzyme 2 (ACE2) as a receptor for cell entry and the transmembrane cell protease serine 2 to activate the viral spike protein (S) for membrane fusion. ACE2 is expressed in the oral mucosa, the respiratory tract, and the intestine. Some studies in children have found lower expression of ACE2 in the nasal epithelium and lungs compared to adults, which may contribute to the differences observed in the pathogenesis of the disease ${ }^{13,14}$.

At present, there is no specific treatment for COVID19. The fundamental approaches are supportive therapy, oxygenation, ventilatory support in severe cases, control of the inflammatory response cascade, and immunomodulation ${ }^{15}$. Since the beginning of the pandemic, drugs that have shown some efficacy in severe acute respiratory syndrome and Middle East respiratory syndrome epidemics, also caused by coronaviruses, were used in adult patients. Among these drugs, the use of chloroquine and hydroxychloroquine was suggested, initially alone and later in combination with azithromycin, based on its in vitro antiviral activity and some clinical evidence. After a few months, the effectiveness of these drugs has been questioned, as they seem to favor mortality, either directly or due to their adverse effects ${ }^{16-19}$. Given the lower frequency of moderate-to-severe infections in children, no controlled clinical studies exist to suggest the efficacy of any of these drugs.

Multiple and different features have been observed in children infected with SARS-Cov-2, and probably new characteristics will continue to appear. Evidence on epidemiological behavior in children shows a lower frequency of infection, less severe illness, lower mortality, and a low capacity to transmit the virus compared to adults. Some of these characteristics can be biologically explained, but there is no evidence to support some of the other aspects.

Biological and immune response differences between children and adults should be identified to define the most appropriate treatments for each age group and to determine the action to prevent infections. Considering that the immune response is different between the child and the adult, vaccines will require different assessments and special surveillance to ensure their adequate efficacy and safety.

\section{References}

1. Zhu N, Zhang D, Wang W, Li X, Yang B, Song J, et al. A novel coronavirus from patients with pneumonia in China, 2019. N Engl J Med. 2020;382:727-33.

2. Li Q, Guan X, Wu P, Wang X, Zhou L, Tong Y, et al. Early transmission dynamics in Wuhan, China, of novel coronavirus-infected pneumonia. N Engl J Med. 2020;382:1199-207.

3. Worldometer. United States of America: Coronavirus. Available from: https://www.worldometers.info/coronavirus.

4. Gobierno de México. México: COVID-19 México. Available from: https:// www.coronavirus.gob.mx/datos.

5. Lu X, Zhang L, Du H, Zhang J, Li YY, Qu J, et al. SARS-CoV-2 infection in children. N Engl J Med. 2020;382:1663-5

6. Singh T, Heston SM, Langel SN, Blasi M, Hurst JH, Fouda GG, et al. Lessons from COVID-19 in children: key hypotheses to guide preventative and therapeutic strategies. Clin Infect Dis. 2020;2020:ciaa547.

7. Center for Disease Control and Prevention. Coronavirus Disease 2019 in Children-United States. Morbidity and Mortality Weekly Report (MMWR); 2020. Available from: https://www.cdc.gov/mmwr/volumes/69/ $\mathrm{wr} / \mathrm{mm} 6914 \mathrm{e} 4 . \mathrm{htm}$.

8. Posfay-Barbe KM, Wagner N, Gauthey M, Moussaoui D, Loevy N, Diana $A$, et al. COVID-19 in children and the dynamics of infection in families. Pediatrics. 2020;2020:e20201576.

9. Wu Q, Zing Y, Shi L, Li W, Gao Y, Pan S, et al. Co-infection and other clinical characteristics of COVID-19 in children. Pediatrics. 2020;2020: e20200961.

10. Cai J, Xu J, Lin D, Zhang J. Xu L, Qu Z, et al. A case series of children with 2019 novel coronavirus infection: clinical and epidemiological features. Clin Infect Dis. 2020;2020:ciaa198.

11. National Centre for Immunization Research and Surveillance. New South Wales: COVID-19 in Schools-the Experience in NSW. Available from: http://www.ncirs.org.au/sites/default/files/2020-04/NCIRS\%20NSW\%20 Schools\%20COVID_Summary_FINAL\%20public_26\%20April\%20 2020.pdf.

12. Lee B, Raszka WV Jr. COVID-19 transmission and children: the child is not to blame. Pediatrics. 2020;2020:004879.

13. Hoffmann $M$, Kleine-Weber $H$, Schroeder $S$, Krüger $N$, Herrler $T$, Erichsen S, et al. SARS-CoV-2 cell entry depends on ACE2 and TMPRSS2 and is blocked by a clinically proven protease inhibitor. Cell. 2020;181:271-80.

14. Bunyavanich S, Do A, Vicencio A. Nasal gene expression of angiotensin-converting enzyme 2 in children and adults. JAMA. 2020;323:2427-9.

15. Gobierno de México. Secretaría de Salud Lineamientos para la prevención detección y atención de COVID-19 en niñas, niños y adolescentes (NNA). Available from: https://coronavirus.gob.mx/wp-content/uploads/2020/05/Lineamientos prevencion deteccion atencion COVID NNA-1.pdf.

16. Gautret $P$, Lagier JC, Parola $P$, Hoang VT, Meddeb L, Mailhe M, et al Hydroxychloroquine and azithromycin as a treatment of COVID-19: results of an open-label non-randomized clinical trial. Int $\mathrm{J}$ Antimicrob Agents. 2020;2020:105949.

17. Wang M, Cao R, Zhang L, Yang X, Liu J, Xu M, et al. Remdesivir and chloroquine effectively inhibit the recently emerged novel coronavirus (2019-nCoV) in vitro. Cell Res. 2020;30:269-71.

18. Mehra MR, Desai SS, Ruschitzka F, Patel AN. Hydroxychloroquine or chloroquine with or without a macrolide for treatment of COVID-19: a multinational registry analysis. Lancet. 2020;6736:31249-6.

19. Tang W, Cao Z, Han M, Wang Z, Chen J, Sun W, et al. Hydroxychloroquine in patients with mainly mild to moderate coronavirus disease 2019: open-label, randomised controlled trial. BMJ. 2020;369:m1849. 